\title{
INDEKS PENDIDIKAN MULTIKULTURAL DAN TOLERANSI SISWA SMA/K DI GUNUNGKIDUL DAN KULONPROGO
}

\section{MULTICULTURAL EDUCATION INDEX AND TOLERANCE OF SMA/K STUDENTS IN GUNUNGKIDUL AND KULONPROGO}

\author{
Umi Muzayanah \\ Balai Penelitian dan Pengembangan Agama Semarang \\ Alamat: Jl. Untung Suropati Kav. 70 Bambankerep Ngaliyan Semarang Jawa Tengah \\ Telp. (024) 7601327, Facs. (024) 7611386 \\ e-mail: umimoza78@gmail.com
}

Naskah diterima 10 Mei 2017, direvisi 30 Mei 2017, disetujui 19 Juni 2017

\begin{abstract}
The study of multiculturalism becomes interesting when it is associated with the fact that in the diversity of Indonesian society, cases of intolerance are still prevalent in some parts of Indonesia. Even some surveys show that intolerance has become widespread among students. Using a quantitative approach, this study aims to measure the index of multicultural education and student tolerance in SMA/K in Gunungkidul and Kulonprogo Yogyakarta. The results showed that the index of multicultural education in Gunungkidul reached 4.06 and Kulonprogo reached 4.16, both included "high" category. While the index of student tolerance in Gunungkidul reached 3.57 and Kulonprogo reached 3.72, and both included "high" category. The multicultural education index and student tolerance index in Gunungkidul and Kulonprogo have no significant differences. From the research results also obtained data that $7.87 \%$ of SMA/K in Gunungkidul and Kulonprogo states "agree" and "strongly agree" to acts of violence in the name of religion.
\end{abstract}

Keywords: Multicultural Education, Tolerance, SMA/K, Gunungkidul, Kulonprogo

\begin{abstract}
Abstrak
Kajian multikulturalisme menjadi menarik ketika dikaitkan dengan kenyataan bahwa dalam keragaman masyarakat Indonesia, kasus intoleransi masih marak terjadi di beberapa wilayah di Indonesia. Bahkan beberapa survey menunjukkan bahwa sikap intoleransi sudah meluas ke kalangan pelajar. Dengan menggunakan pendekatan kuantitatif, penelitian ini bertujuan untuk mengukur indeks pendidikan multikultural dan toleransi siswa di SMA/K di Gunungkidul dan Kulonprogo Yogyakarta. Hasil penelitian menunjukkan bahwa indeks pendidikan multikultural di Gunungkidul mencapai 4,06 dan Kulonprogo mencapai 4,16, keduanya termasuk kategori "tinggi". Sedangkan indeks toleransi siswa di Gunungkidul mencapai 3,57 dan Kulonprogo mencapai 3,72, dan keduanya termasuk kategori "tinggi". Indeks Pendidikan multikultural dan indeks toleransi siswa di Gunungkidul dan Kulonprogo tidak memiliki perbedaan signifikan. Dari hasil penelitian juga diperoleh data bahwa 7,87\% siswa SMA/K di Gunungkidul dan Kulonprogo menyatakan "setuju" dan "sangat setuju" terhadap aksi kekerasan yang mengatasnamakan agama.
\end{abstract}

Kata Kunci: Pendidikan Multikultural, Toleransi, SMA/K, Gunungkidul, Kulonprogo 


\section{PENDAHULUAN}

Fakta bahwa Indonesia merupakan negara multikultur belum sepenuhnya dipahami dan disadari oleh seluruh warga negara. Hal ini ditandai dengan masih maraknya kasus-kasus yang masuk pada tindak intoleran yang cenderung meningkat. The Wahid Institute mencatat kasus pelanggaran kebebasan beragama dan berkeyakinan di berbagai daerah di Indonesia Tahun 2011 mencapai 92 kasus. Bentuk pelanggaran kebebasan beragama dan berkeyakinan yang paling tinggi adalah pelarangan atau pembatasan aktivitas keagamaan atau kegiatan ibadah kelompok tertentu. ${ }^{1}$ The Wahid Institute juga mencatat kasus intoleransi secara umum yang terjadi meningkat dari 184 pada 2010 menjadi 276 kasus pada tahun 2011 dan 274 kasus pada tahun 2012. ${ }^{2}$

Sebagai bagian dari wilayah di Indonesia, Yogyakarta merupakan salah satu provinsi yang penduduknya cukup heterogen, baik dari sisi agama, suku, maupun budaya. Meski mayoritas penduduknya beragama Islam (92,20\%), namun penganut agama Kristen, Katolik, Hindu, Budha, Konghucu dan lainnya juga menjadi bagian dari masyarakat Yogyakarta. $^{3}$ Bahkan Kota Yogyakarta

${ }^{1}$ Rini Fidiyani. 2013. "Kerukunan Umat Beragama di Indonesia: Belajar Keharmonisan dan Toleransi Umat Beragama di Desa Cikakak Kec. Wangon Kabupaten Banyumas". Jurnal Dinamika Hukum, 13 (3): 468-482.

${ }^{2}$ Jimly Asshiddiqie. 2014. Toleransi dan Intoleransi Beragama di Indonesia Pasca Reformasi. Makalah disampaikan pada Dialog Kebangsaan tentang “Toleransi Beragama”, Ormas Gerakan Masyarakat Penerus Bung Karno, di Hotel Borobudur Jakarta, 13 Februari, 2014.

${ }^{3}$ Badan Pusat Statistik. 2015. Daerah Istimewa Yogyakarta Dalam Angka 2015, h. 108. memiliki slogan "city of tolerance" yang dikukuhkan pada tanggal 3 Maret 2011 oleh Wali Kota Yogyakarta. ${ }^{4}$

Slogan "city of tolerance" dikeluarkan oleh Pemerintah Kota Yogyakarta didasarkan atas heterogennya warga kota tersebut. ${ }^{5}$ Ironisnya slogan city of tolerance yang melekat pada Kota Yogyakarta saat ini dipertanyakan relevansinya dengan kondisi empiris di kota tersebut. Subkhi, aktivis Jaringan Intelektual Muda Muhammadiyah (JIMM) menyebutkan adanya berbagai aksi intoleransi yang terjadi di Kota Yogyakarta, salah satunya ditandai dengan bertebarannya spandukspanduk anti Syiah. ${ }^{6}$ Bahkan berdasarkan hasil kajian Setara Institut menempatkan Yogyakarta dalam lima besar provinsi di Indonesia dengan angka pelanggaran tertinggi terkait kebebasan beragama dan berkeyakinan. Hal ini ditengarai karena dinamika kepemimpinan lokal, tumbuhnya kelompok-kelompok sosial yang memiliki wajah dan tindakan intoleran, dan lemahnya kontrol legal dan kontrol sosial. ${ }^{7}$

Selain Kota Yogyakarta, Gunungkidul merupakan wilayah yang keberadaannya memberikan kontribusi keberagaman di Provinsi D.I. Yogyakarta. Dilihat dari agama yang dianut oleh penduduknya, dua wilayah ini didiami oleh mayoritas muslim yang mencapai 95,73\%. Selain Islam, penduduk

${ }^{4}$ Danang Prabowo. 2011. "Yogyakarta Dikukuhkan sebagai Kota Toleran”. Diakses tanggal 14 Oktober 2016 dari www.news.okezone.com.

${ }^{5}$ Komang Adhyatma. 2016. "Street Artist Yogyakarta Bereaksi Mengenai Jargon City of Tolerance". Diakses tanggal 14 Oktober 2016 dari www.kanaltigapuluh.info.

${ }^{6}$ Wijaya Kusuma. 2014. "Slogan 'Yogyakarta City of Tolerance"' Dipertanyakan. Diakses tanggal 14 Oktober 2016 dari www.regional.kompas.com.

${ }^{7}$ Op. Cit. 
di wilayah ini berasal dari pemeluk agama Katolik, Kristen, Hindu, Budha, serta Khonghucu. ${ }^{8}$ Meski tingkat heterogenitas masyarakat Gunungkidul tidak setinggi Kota Yogyakarta dan Kabupaten Sleman, namun keragaman yang dimiliki wilayah ini memiliki potensi gesekan antaragama yang tidak bisa diabaikan. Dari catatan Lembaga Bantuan Hukum (LBH) Yogyakarta, tindakan intoleran yang pernah terjadi di Gunungkidul adalah kekerasan terhadap Ketua Forum Lintas Iman dan penolakan Paskah Adiyuswa. Tindakan intoleran tersebut merupakan dua dari 13 peristiwa pelanggaran hak atas kebebasan beragama dan berkeyakinan di Yogyakarta pada kurun waktu 2011-2015. ${ }^{9}$

Berbeda dengan Gunungkidul. Kabupaten Kulonprogo yang juga didominasi oleh pemeluk agama Islam (94,34\%) memiliki kasus intoleransi yang tidak terlalu tajam. Kasus intoleransi yang terjadi di Kulonprogo didominasi oleh persoalan tempat ibadah. ${ }^{10}$ Namun demikian bukan berarti Kulonprogo aman dari kasus-kasus intoleransi yang melibatkan beberapa kelompok berbeda dalam konflik horizontal.

Ironi yang terjadi antara slogan "city of tolerance" dengan kondisi nyata yang menempatkan Yogyakarta sebagai wilayah darurat intoleransi beragama menyisakan sebuah pertanyaan masih relevankah slogan tersebut disematkan pada provinsi DIY,

\footnotetext{
8 Badan Pusat Statistik. 2015. Daerah Istimewa Yogyakarta Dalam Angka 2015, h. 201.

9 Muh. Syaifullah. 2016. "Yogyakarta Dinilai sebagai Kota Intoleran”. Diakses tanggal 14 Oktober 2016 dari www.m.tempo.com.

10 "FKUB Antisipasi Tindakan Intoleransi Umat Beragama di Kulonprogo". Diakses tanggal 14 Oktober 2016 dari www.jogja.tribunnews.com.
}

khususnya Kota Yogyakarta. Berbagai kasus terkait kebebasan beragama yang terjadi di provinsi DIY sedikit banyak menjadi ancaman bagi keharmonisan kehidupan masyarakatnya yang notabene bersifat multikultur. Oleh karenanya, pemahaman tentang pentingnya wawasan ke-Indonesiaan yang multikultur perlu ditanamkan di tiap lingkungan, tidak terkecuali lingkungan sekolah. Wawasan multikulturalisme di lingkungan sekolah dapat diterapkan melalui pengembangan pendidikan multikultural.

Pendidikan multikultural pada dasarnya bertujuan untuk memberikan kesadaran kultural dan pemberian kesempatan yang sama kepada seluruh siswa untuk belajar di tengah keragaman. ${ }^{11}$ Zamroni (2011) menjelaskan bahwa pendidikan multikultural dapat menjadi sarana untuk menjadikan masyarakat memiliki sikap toleran dalam kehidupan bermasyarakat. ${ }^{12}$ Dengan demikian pendidikan multikultural di Indonesia memiliki urgensi yang tinggi di tengah keberagaman yang dimilikinya.

Kajian tentang pendidikan multikultural telah dilakukan melalui beberapa penelitian terdahulu. Di antaranya adalah penelitian yang dilakukan oleh Ahmad Hidayatullah Al Arifin (2012) dan Rustam Ibrahim (2013). Keduanya mengkaji pendidikan multikultural dalam tataran konseptual. Kajian pendidikan multikultural juga pernah dilakukan oleh Balai Penelitian dan Pengembangan Agama Semarang (2015). Salah satu hasil penelitian menyebutkan

${ }^{11}$ Zakiyuddin Baidhawy. 2005. Pendidikan Agama Berwawasan Multikultural. Jakarta: Erlangga, h. 108.

${ }^{12}$ Akhmad Hidayatullah Al Arifin. 2012. "Implementasi Pendidikan Multikultural dalam Praksis Pendidikan di Indonesia". Jurnal Pembangunan Pendidikan: Fondasi dan Aplikasi, 1 (1): 72-82. 
bahwa budaya sekolah berperan penting dalam penerapan pendidikan multikultural di tingkat SMA. ${ }^{13}$ Berbeda dengan penelitian sebelumnya, penelitian ini menghasilkan sebuah indeks pendidikan multikultural di SMA/K sehingga pelaksanaan pendidikan mutikultural di sekolah dapat lebih terukur. Selain itu, penelitian ini juga memberikan informasi tingkat toleransi siswa SMA/K di wilayah Gunungkidul dan Kulonporogo.

Terkait dengan fungsi pendidikan multikultural sebagai alat untuk menjadikan masyarakat yang toleran dan bersifat inklusif, maka pendidikan multikultural di lingkungan sekolah pun dapat diarahkan pada pembentukan karakter siswa yang toleran dan menghargai perbedaan. Kajian pendidikan multikultural di DIY menjadi penting untuk mengetahui peran sekolah dalam memberikan ruang bagi tumbuhnya pemahaman multikultural di DIY. Hal ini dapat dilakukan dengan mengukur indeks pendidikan multikultural di wilayah DIY, khususnya di Kabupaten Gunungkidul dan Kabupaten Kulonprogo. Selainitu, penelitian ini juga mengukur indeks toleransi siswa di sekolah umum sebagai salah satu effect dari pelaksanaan pendidikan multikultural di sekolah. Kedua tujuan penulisan tersebut merupakan jawaban terhadap permasalahan penelitian, yaitu seberapa tinggi indeks pendidikan multikultural dan toleransi siswa pada sekolah umum, khususnya di SMA dan SMK di Gunungkidul dan Kulonprogo.

13 Yustiani. 2015. "Epilog Pendidikan Agama Berwawasan Multikultural". Dalam Pendidikan Multikultural di Pulau Dewata. Ed. Mulyani Mudis Taruna. Yogyakarta: Arti Bumi Intaran, h. 316-319.

\section{Kerangka Konseptual}

\section{Pendidikan Multikultural}

Penerapan pendidikan multikultural di Indonesia memiliki urgensi yang cukup tinggi mengingat Indonsia merupakan salah satu negara multikultur terbesar di dunia. Dalam catatan sejarah, tidak sedikit kasus yang menyebabkan perpecahan dan ancaman disintegrasi bangsa. ${ }^{14}$ Oleh karenanya, pendidikan multikultural dilakukan sebagai upaya pengenalan keragaman budaya, etnis, suku, dan agama kepada siswa melalui penyelenggaraan pendidikan di sekolah.

Pendidikan multikultural secara terminologis berarti proses pengembangan potensi manusia yang menghargai pluralitas sebagai implikasi dari adanya keragaman budaya, etnis, suku, dan aliran (agama). ${ }^{15}$ Dalam kaitan dengan penyelenggaraan pendidikan di lingkungan sekolah, pendidikan multikultural merupakan strategi pendidikan yang diterapkan di seluruh mata pelajaran dengan berbasis keragaman siswa baik etnis, agama, bahasa, gender, kelas sosial, kemampuan, maupun umur sehingga proses belajar dapat berjalan efektif. ${ }^{16}$ Dengan kata lain, pendidikan multikultural merupakan strategi untuk menjawab keragaman. ${ }^{17}$ Dengan demikian, pendidikan multikultural dapat diterapkan

\footnotetext{
${ }^{14}$ M. Ainul Yaqin. 2007. Pendidikan Multikultural Cross-Cultural Understanding untuk Demokrasi dan Keadilan. Yogyakarta: Pilar Media, h. 25.

${ }^{15}$ Rustam Ibrahim. 2013. “Pendidikan Multikultural: Pengertian, Prinsip, dan Relevansinya dengan Tujuan Pendidikan Islam". ADDIN, 7 (1): 129154.

${ }^{16}$ Op. Cit.

${ }^{17}$ Zakiyuddin Baidhawy. 2005. Pendidikan Agama Berwawasan Multikultural. Jakarta: Erlangga, h. 108.
} 
pada setiap mata pelajaran, dengan mengintegrasikan nilai-nilai menghargai perbedaan dan keragaman yang dimiliki siswa.

Kebijakan pendidikan multikultural di Indonesia tidak secara eksplisit diatur dalam peraturan perundangan. Salah satu prinsip penyelenggaraan pendidikan yang relevan dengan pendidikan multikultural dituangkan dalam Undang-undang No. 23 Tahun 2003, bahwa pendidikan diselenggarakan secara demokratis dan berkeadilan serta tidak diskriminatif dengan menjunjung tinggi hak asasi manusia, nilai keagamaan, nilai kultural, dan kemajemukan bangsa. Untuk menyelenggarakan pendidikan yang demokratis, terdapat tiga syarat pokok yang harus dipenuhi. Pertama, praktik pendidikan senantiasa menekankan pada prinsip keadilan sehingga seluruh siswa memperoleh pendidikan yang adil dan setara. Kedua, proses pembelajaran dijauhkan dari sifat bias dan stereotip. Ketiga, proses pembelajaran berujung pada pengembangan kesadaran siswa akan dirinya, menghargai kultur lain di luar dirinya, dan mampu bekerjasama di tengah perbedaan kultur yang ada. ${ }^{18}$

James Banks menjelaskan lima dimensi pendidikan multikultural, yaitu integrasi isi/materi, konstruksi pengetahuan, pengurangan prasangka, pendidikan yang sama/adil, dan pemberdayaan budaya sekolah dan struktur sosial. ${ }^{19}$ Masih

\footnotetext{
${ }^{18}$ Zamroni. 2011. Pendidikan Demokrasi pada Masyarakat Multikultural. Yogyakarta: Gavin Kalam Utama, h. 33-34.

${ }^{19}$ Rustam Ibrahim. 2013. "Pendidikan Multikultural: Pengertian, Prinsip, dan Relevansinya dengan Tujuan Pendidikan Islam". ADDIN, 7 (1): 129154.
}

menurut Banks, pelaksanaan pendidikan multikultural di lingkungan sekolah dapat dilihat dari beberapa indikator, di antaranya adalah (1) kebijakan pendidikan yang mendukung keragaman, (2) sikap positif tenaga kependidikan terhadap keberagaman peserta didik, (3) kurikulum yang transformasional dan tindakan terfokus pada konsep keberagaman, (4) monitoring terhadap proses pendidikan multikultural oleh pengawas sekolah. ${ }^{20}$ Dari keempat indikator tersebut terlihat bahwa pengembangan budaya sekolah dan proses pembelajaran memiliki peran strategis dalam pelaksanaan pendidikan multikultural.

\section{Toleransi dalam Konteks Keberagamaan}

Toleransi dalam bahasa Indonesia berasal dari kata toleran yang berarti bersifat atau bersikap menenggang (menghargai, membiarkan, membolehkan) pendirian (pendapat, pandangan, kepercayaan, kebiasaan, kelakuan, dan sebagainya) yang berbeda atau bertentangan dengan pendirian sendiri. Sedangkan toleransi mengandung makna sifat atau sikap toleran. ${ }^{21}$ Dengan demikian toleransi merupakan sikap menghargai pandangan, kepercayaan, dan segala sesuatu yang berbeda dengan pandangan dan kepercayaan sendiri. Toleransi tidak berarti seseorang harus mengorbankan kepercayaan atau prinsip yang dianutnya. Dalam toleransi sebaliknya tercermin sikap yang kuat atau

${ }^{20}$ A.M. Wibowo. 2016. Indeks Pendidikan Multikultural di D.I. Yogyakarta. Laporan Penelitian belum Dipublikasi. Balai Penelitian dan Pengembangan Agama Semarang, h. 17.

${ }^{21}$ www.kbbi.web.id. Diakses tanggal 6 Juni 2017. 
istiqamah untuk memegangi keyakinan atau pendapatnya sendiri. ${ }^{22}$

Sikap toleransi sangat diperlukan dalam kehidupan berbangsa, di mana Indonesia memiliki keragaman suku, budaya, bahasa, dan agama. Secara konstitusi, pemerintah menjamin perbedaan yang ada, di mana salah satunya adalah kebebasan beragama dan menjalankan ibadah sesuai dengan agama yang dipeluknya. Namun demikian, tindakan intoleransi masih marak terjadi di sebagian wilayah Indonesia, bahkan cenderung meningkat dari tahun ke tahun. Berdasarkan catatan Komnas HAM, tahun 2014 terjadi 74 kasus intoleransi, tahun 2015 meningkat menjadi 87 kasus, dan tahun 2015 kasus intoleransi hampir mencapai 100 kasus. ${ }^{23}$ Perbedaan keyakinan dan etnik yang bermuatan ekonomi mempengaruhi toleransi/intoleransi. Namun perbedaan agama dan etnik saja tidak berpengaruh secara signifikan terhadap toleransi/ intoleransi. ${ }^{24}$

Ditinjau dari ajaran agama (Islam), ada tiga ajaran toleransi yang terkandung di dalam Al-Quran. Ketiga ajaran toleransi tersebut adalah toleransi dalam keyakinan dan menjalankan peribadahan, toleransi hidup berdampingan dengan agama lain, dan

22 Ajat Sudrajat. Tt. "Agama dan Masalah Kekerasan”. Diakses tanggal 16 Desember 2016 dari www.staff.uny.ac.id.

${ }^{23}$ Lutfi Mairizal Putra. 2017. "Catatan Komnas HAM, Kasus Intoleransi Meningkat Setiap Tahun”. Diakses tanggal 22 Juni 2017 dari www.nasional. kompas.com.

24 Bagus Takwin, dkk. 2016. Studi tentang Toleransi dan Radikalisme di Indonesia Pembelajaran dari 4 Daerah Tasikmalaya, Jogjakarta, Bojonegoro, dan Kupang. International NGO Forum on Indonesian Development, h. viii. toleransi dalam hubungan bermasyarakat. ${ }^{25}$ Toleransi yang terkandung dalam AlQuran tidak hanya terbatas pada toleransi antaragama saja, melainkan juga toleransi dalam interkasi sosial, yang tidak hanya melibatkan kelompok agama lain, melainkan juga suku, etnis, dan budaya yang berbeda.

\section{METODOLOGI PENELITIAN}

Penelitian ini menggunakan metode kuantitatif deskriptif dengan teknik pengumpulan data menggunakan angket/ kuesioner. Kuesioner digunakan untuk menjaring data tentang persepsi siswa terhadap pelaksanaan pendidikan multikultural di sekolah dan sikap toleransi siswa. Melalui persepsi siswa tersebut diperoleh informasi seberapa besar indeks pendidikan multikultural dan indeks toleransi siswa pada SMA/K di Gunungkidul dan Kulonprogo, serta perbedaan indeks di kedua wilayah tersebut.

Populasi penelitian ini adalah seluruh SMA dan SMK di Kabupaten Gunungkidul dan Kulonprogo, baik swasta maupun negeri. Gunungkidul memiliki SMA sebanyak 22 sekolah dan SMK sebanyak 46 sekolah, sedangkan Kulonprogo memiliki SMA sebanyak 16 sekolah dan SMK sebanyak 36 sekolah.

Indeks pendidikan multikultural dan indeks toleransi siswa keduanya diukur melalui persepesi siswa pada SMA/K di Gunungkidul dan Kulonprogo. Persepsi siswa diperoleh melalu angket atau kuesioner yang diberikan kepada siswa dengan mempertimbangkan perbedaan jenis kelamin, agama, suku dan budaya (jika 
memungkinkan), serta status sosial. Oleh karena itu perlu diketahui pula populasi siswa pada jenjang pendidikan menengah di wilayah tersebut.

Populasi siswa SMA/K di Gunungkidul keseluruhan berjumlah 23.154 siswa, yang terdiri dari 5.859 siswa SMA dan 17.295 siswa SMK. Sedangkan jumlah populasi di Kulonprogo adalah 15.635 siswa, yang terdiri dari 4.367 siswa SMA dan 11.268 siswa SMK. Dilihat dari agama yang dipeluk, mayoritas siswa yang menjadi populasi penelitian beragama Islam mencapai 95,17\% untuk wilayah Gunungkidul dan 95,63\% untuk wilayah Kulonprogo.

Pengambilan sampel dimulai dengan penentuan sekolah di Gunungkidul dan Kulonprogo, yang ditentukan dengan acak sederhana dengan mempertimbangkan proporsi antara SMA dan SMK. Sekolah yang diambil sebagai sampel penelitian terdiri dari sekolah negeri dan swasta, di mana sekolah swasta dipilih secara acak dengan mempertimbangkan keterwakilan dari sekolah di bawah yayasan umum, yayasan keagamaan Islam, yayasan keagamaan Kristen, dan yayasan keagamaan Katolik. Selain mempertimbangkan status sekolah dan yayasan penaungnya, pengambilan sekolah juga didasarkan pada keterwakilan kecamatan yang ada di kedua wilayah tersebut.

Di Kabupaten Gunungkidul, sekolah yang menjadi sampel penelitian sebanyak 15 sekolah, yang terletak pada sembilan kecamatan. Jumlah sekolah pada tiap kecamatan yang terpilih sebagai sampel tidak semuanya sama, namun disesuaikan dengan jumlah sekolah yang ada di kecamatan tersebut. Sementara di
Kulonprogo, sekolah yang menjadi sampel penelitian sebanyak 10 sekolah, yang terletak di tujuh kecamatan. Sama halnya dengan Gunungkidul, penentuan sampel penelitian didasarkan pada keterwakilan sekolah negeri dan swasta yang berada di kecamatan secara proporsional.

Selain deskripsi sekolah, perlu juga diuraikan jumlah siswa SMA/K yang menjadi sampel penelitian. Siswa yang menjadi sampel penelitian di Gunungkidul berjumlah 403 siswa dari total populasi 23.154 siswa. Sedangkan sampel penelitian di Kulonprogo berjumlah 245 siswa dari total populasi 15.635 siswa sehingga jumlah sampel seluruhnya 648 siswa. Untuk mengetahui sejauh mana sampel merepresentasikan populasi yang ada dapat digunakan rumus Slovin berikut.

$$
n=\frac{N}{1+N e^{2}}
$$

Dimana N adalah jumlah populasi, $\mathrm{n}$ adalah jumlah sampel, dan e adalah error yang disebabkan karena kesalahan pengambilan sampel. Dengan menggunakan rumus Slovin diperoleh nilai error (e) untuk Gunungkidul sebesar 0,05, yang artinya batas toleransi akibat kesalahan sampling sebesar $5 \%$. Sedangkan nilai e pada pengambilan sampel di Kulonprogo sebesar 0,06, yang artinya bahwa toleransi akibat kesalahan sampling sebesar $6 \%$.

Indeks pendidikan multikultural di sekolah diukur melalui persepsi siswa terhadap pelaksanaan pendidikan multikultural di sekolahnya, yang dijaring melalui kuesioner. Indikator yang digunakan dalam menyusun kuesioner mengacu pada Benchmarks Multikultural yang dikembangkan oleh James Banks 
(2002), yang mencakup empat indikator pendidikan multikultural, yaitu (1) kebijakan pendidikan yang mendukung keragaman, (2) sikap positif tenaga kependidikan terhadap keberagaman peserta didik, (3) kurikulum yang transformasional dantindakan terfokus pada konsep keberagaman, (4) monitoring terhadap proses pendidikan multikultural oleh pengawas sekolah. ${ }^{26}$ Selain indeks pendidikan multikultural, penelitian ini juga mengukur indeks toleransi siswa dalam kehidupan sosialnya, baik di lingkungan sekolah maupun masyarakat.

Uji validitas dilakukan melalui prosedur korelasi product moment, yaitu dengan menghitung korelasi skor tiap butir instrumen dengan skor total. Butir instrumen dikatakan valid jika nilai korelasi yang diperoleh $>\mathrm{r}$ tabel. Dari jumlah responden 138 orang diperoleh nilai $r$ tabel sebesar 0,141. Dengan menggunakan software SPSS, butir instrumen yang tidak valid sebanyak 7 butir, yaitu butir nomor $26,36,37,50,52,53$, dan 56. Butir yang tidak valid sebagian digugurkan dan sebagian lagi dipertahankan dengan melakukan revisi kalimat, dengan pertimbangan bahwa substansi butir tersebut sangat penting untuk mendukung hasil penelitian.

Selain validitas, kuesioner penelitian juga diuji tingkat reliabilitasnya, yang dalam penelitian ini menggunakan koefisien alpha cronbach. Dengan berbantuan SPSS diperoleh nilai koefisien alpha cronbach 0,904 atau mendekati 1 . Artinya bahwa instrumen penelitian telah memenuhi syarat reliabel.

${ }^{26}$ A.M. Wibowo. 2016. Indeks Pendidikan Multikultural di D.I. Yogyakarta. Laporan Penelitian belum dipublikasi. Balai Penelitian dan Pengembangan Agama Semarang, h. 17.
Skala penilaian yang digunakan dalam penelitian ini adalah skala Likert, dengan lima pilihan jawaban (1 sampai 5). Skor 1 merupakan skor terendah dan skor 5 adalah skor tertinggi. Untuk butir kuesioner yang bersifat negatif (unvaforable) penskoran dilakukan secara terbalik, yaitu skor 1 merupakan skor tertinggi dan 5 adalah skor terendah.

Untuk menghitung indeks pendidikan multikultural dan indeks toleransi siswa digunakan nilai rata-rata yang selanjutnya diinterpretasikan secara kualitatif dengan lima kategori/kriteria. Untuk menentukan interval pada tiap kategori diperoleh dari selisih skor maksimal dan minimal kemudian dibagi jumlah kategori yang diinginkan. Dengan menentukan lima kategori maka diperoleh panjang interval 0,80 sehingga kategori indeks pendidikan multikultural dan indeks toleransi siswa adalah:

Tabel 1 Kategori Indeks

\begin{tabular}{ll}
\hline Nilai rata-rata & Kriteria \\
\hline $1,00-1.80$ & Sangat Rendah \\
$1.81-2.61$ & Rendah \\
$2.62-3.42$ & Cukup \\
$3.43-4.23$ & Tinggi \\
$4.24-5.00$ & Sangat Tinggi \\
\hline
\end{tabular}

Analisis data dalam penelitian ini dilakukan dengan pendekatan kuantitatif. Untuk mengukur indeks pendidikan multikultural di sekolah dan indeks toleransi siswa digunakan analisis kuantitatif deskriptif dengan menghitung rata-rata. Sedangkan untuk menguji ada tidaknya perbedaan indeks pendidikan multikultural dan sikap toleransi siswa di Gunungkidul dan Kulonprogo digunakan analisis uji 
beda melalui prosedur independent $t$ test. Dengan kata lain, pendekatan kuantitatif juga digunakan untuk membuktikan hipotesis nol bahwa tidak ada perbedaan indeks pendidikan multikultural dan indeks toleransi siswa SMA/K di Gunungkidul dan Kulonprogo.

\section{HASIL DAN PEMBAHASAN}

\section{Indeks Pendidikan Multikultural di Sekolah}

Untuk mengetahui tingkat pendidikan multikultural di sekolah perlu diukur sebuah indeks yang bisa menggambarkan kondisi riil di sekolah. Indeks ini diperoleh melalui rata-rata yang diperoleh dari persepsi siswa terhadap pelaksanaan pendidikan multikultural di sekolahnya. Dalam penelitian ini, indeks pendidikan multikultural diperoleh melalui kusioner yangdibagikankepadasiswauntukmengukur ketercapaian pendidikan multikultural dilihat dari empat indikator, yaitu 1) kebijakan sekolah, 2) sikap positif pegawai, 3) kurikulum yang transformasional, dan 4) monitoring pendidikan. Secara umum, indeks pendidikan multikultural di SMA dan SMK di Gunungkidul dan Kulonprogo terlihat pada tabel berikut:

Tabel 2 Indeks Pendidikan Multikultural di Sekolah

\begin{tabular}{|c|c|c|c|c|c|}
\hline \multicolumn{6}{|c|}{ Group Statistics } \\
\hline & Kabupaten & $\mathrm{N}$ & Mean & Std. Deviation & Std. Error Mean \\
\hline \multirow{2}{*}{ Mean } & Gunungkidul & 403 & 4,0620 & ,36392 & ,01813 \\
\hline & Kulonprogo & 245 & 4,1625 & 37190 & ,02376 \\
\hline
\end{tabular}

Sumber: Hasil Penelitian (Data diolah)

Tabel di atas menunjukkan bahwaindeks pendidikan multikultural di lingkungan sekolah untuk wilayah Gunungkidul sebesar
4,06 dan Kulonprogo sebesar 4,16. Dengan menggunakan skala pengukuran 1 sampai 5, indeks pendidikan multikultural di kedua wilayah tersebut tergolong "tinggi". Indeks pendidikan multikultural tersebut merupakan indeks secara umum yang terdiri dari empat indikator sebagaimana dijelaskan sebelumnya. Indeks pendidikan multikultural di Gunungkidul lebih rendah dibanding dengan Kulonprogo, dengan selisih atau gap yang diperoleh mencapai -0,113. Artinya penerapan pendidikan multikultural pada SMA/K di Kabupaten Kulonprogo lebih baik dibanding Gunungkidul.

Perbedaan indeks antara Gunungkidul dan Kulonprogo, jika dilihat dari gap yang muncul relatif kecil. Untuk itu perlu dilakukan uji lebih lanjut melalui prosedur independent t-test yang akan memberikan informasi tentang signifikansi perbedaan indeks pendidikan multikultural di kedua wilayah tersebut, dengan hipotesis sebagai berikut:

$\mathrm{H}_{0} \quad$ : rata-rata/indeks di Gunungkidul = rata-rata/indeks di Kulonprogo

$\mathrm{H}_{1} \quad$ : rata-rata/indeks di Gunungkidul $\neq$ rata-rata/indeks di Kulonprogo

Dengan menggunakan $\alpha=0,05$, kriteria $\mathrm{H}_{0}$ ditolak apabila nilai sig. $<\alpha(0,05)$, dihasilkan informasi sebagai berikut.

Tabel 3 Hasil Uji Beda Indeks Pendidikan Multikultural

\begin{tabular}{|c|c|c|c|c|c|c|c|}
\hline & & \multicolumn{2}{|c|}{$\begin{array}{l}\text { Levene's Test } \\
\text { for Equality } \\
\text { of Variances }\end{array}$} & \multicolumn{3}{|c|}{ t-test for Equality of Means } & \multirow[b]{2}{*}{$\begin{array}{l}\text { Std. Error } \\
\text { Difference }\end{array}$} \\
\hline & & $\mathrm{F}$ & Sig. & $T \quad d f$ & $\begin{array}{l}\text { Sig. } \\
\text { (2-tailed) }\end{array}$ & $\begin{array}{l}\text { Mean } \\
\text { Difference }\end{array}$ & \\
\hline \multirow{2}{*}{$\begin{array}{l}\text { Rata-rata } \\
\text { kabupaten }\end{array}$} & $\begin{array}{l}\text { Equal } \\
\text { variances } \\
\text { assumed }\end{array}$ & ,093 & ,761 & $-3,382646$ &, 001 &,- 10055 & ,02973 \\
\hline & $\begin{array}{l}\text { Equal } \\
\text { variances } \\
\text { not } \\
\text { assumed }\end{array}$ & & & $-3,365506,562$ & ,001 &,- 10055 & ,02989 \\
\hline
\end{tabular}

Sumber: Hasil Penelitian (Data diolah) 
Berdasarkan output SPSS diketahui bahwa nilai sig. yang diperoleh sebesar $0,761>0,05$ sehingga dapat disimpulkan bahwa tidak terdapat perbedaan antara rata-rata Gunungkidul dan rata-rata Kulonprogo. Artinya indeks pendidikan multikultural pada SMA/K di Gunungkidul dan Kulonprogo tidak memiliki perbedaan secara signifikan. Dengan demikian pendidikan multikultural yang diterapkan di sekolah jenjang pendidikan menengah di Kulonprogo secara signifikansi tidak lebih baik dari Gunungkidul.

Selanjutnya, untuk mengetahui perbedaan indeks pendidikan multikultural di SMA dan SMK perlu dilihat rata-rata indeks dari kedua jenis sekolah tersebut. Dari 289 siswa SMA dan 359 siswa SMK yang menjadi sampel penelitian, diperoleh rata-rata indeks pendidikan multikultural sebagai berikut.

Tabel 4 Indeks Pendidikan Multikultural Berdasarkan Jenis Sekolah

\begin{tabular}{llllll}
\hline \multicolumn{5}{c}{ Group Statistics } \\
\hline & Jenis sekolah & $N$ & Mean & $\begin{array}{l}\text { Std. } \\
\text { Deviation }\end{array}$ & $\begin{array}{l}\text { Std. Error } \\
\text { Mean }\end{array}$ \\
\hline $\begin{array}{l}\text { Rata-rata } \\
\text { multikultural }\end{array}$ & SMA & 289 & 4,0899 &, 38762 &, 02280 \\
\cline { 2 - 6 } & SMK & 359 & 4,1081 &, 35534 &, 01875 \\
\hline
\end{tabular}

Sumber: Hasil Penelitian (Data diolah)

Berdasarkan tabel di atas diperoleh rata-rata indeks pendidikan multikultural di SMA sebesar 4,09 dan SMK sebesar 4,11. Indeks pendidikan multikultural di kedua jenis sekolah tersebut berada pada kategori "tinggi", di mana SMK memiliki indeks lebih tinggi dibanding SMA. Namun untuk mengetahui perbedaan indeks di kedua sekolah tersebut dilakukan uji beda, dengan hasil sebagai berikut.
Tabel 5 Uji Beda Indeks Pendidikan Multikultural di SMA dan SMK

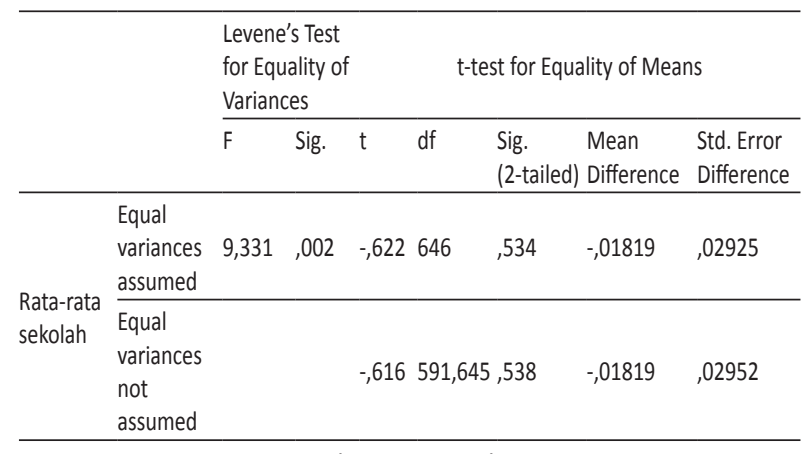

Sumber: Hasil Penelitian (Data diolah)

Tabel 9 memperlihatkan nilai sig sebesar $0,002<\alpha(0,05)$ sehingga terjadi penolakan $\mathrm{H}_{0}$. Artinya indeks pendidikan multikultural di SMA berbeda secara signifikan dengan indeks pendidikan multikultural di SMK. Artinya, pelaksanaan pendidikan multikultural di SMK lebih baik dibanding SMA.

\section{Indeks Toleransi Siswa di Sekolah}

Pendidikan multikultural merupakan sarana untuk menjadikan masyarakat memiliki sikap toleran. ${ }^{27}$ Dengan demikian, salah satu effect pendidikan multikultural di sekolah adalah terbentuknya sikap toleransi di lingkungan sekolah, khususnya bagi siswa. Toleransi yang dimaksud di sini tidak terbatas pada toleransi antar umat beragama, namun juga toleransi terhadap segala perbedaan yang ada di sekitarnya, di antaranya adalah perbedaan jenis kelamin, agama, suku, budaya, dan bahasa.

Sebagaimana pengukuran indeks pendidikan multikultural, untuk mengukur

${ }^{27}$ Zamroni (2011) dalam Akhmad Hidayatullah Al Arifin. 2012. "Implementasi Pendidikan Multikultural dalam Praksis Pendidikan di Indonesia". Jurnal Pembangunan Pendidikan: Fondasi dan Aplikasi, 1 (1): 7282. 
indeks sikap toleransi siswa juga dilakukan melalui penyebaran angket kepada siswa, dengan jumlah item sebanyak 12 item, dengan menggunakan skala penilaian 1 sampai 5. Dengan langkah yang sama maka diperoleh indeks toleransi siswa sebagai berikut.

\begin{tabular}{cccccc}
\multicolumn{6}{c}{ Tabel 6 Indeks Toleransi Siswa di Gunungkidul dan } \\
Kulonprogo \\
\hline kabupaten & N & Mean & $\begin{array}{c}\text { Std. } \\
\text { Deviation }\end{array}$ & $\begin{array}{c}\text { Std. Error } \\
\text { Mean }\end{array}$ \\
\hline \multirow{2}{*}{ ratatoleransi } & Gunungkidul & 403 & 3,5670 &, 45899 &, 02286 \\
\cline { 2 - 6 } & Kulon progo & 245 & 3,7238 &, 49728 &, 03177 \\
\hline
\end{tabular}

Sumber: Hasil Penelitian (Data diolah)

Berdasarkan Tabel 10 dapat dilihat nilai rata-rata toleransi siswa di Gunungkidul sebesar 3,57 dan Kulonprogo sebesar 3,72. Indeks toleransi siswa di kedua wilayah tersebut masuk pada kategori "tinggi". Sebagaimana indeks pendidikan multikultural, Kulonprogo juga memiliki indeks toleransi siswa lebih tinggi dibanding Gunungkidul. Untuk mengetahui signifikansi perbedaan indeks toleransi di kedua wilayah tersebut, dilakukan uji beda dengan hasil sebagai berikut.

Tabel 7 Uji Beda Indeks Toleransi Siswa di Gunungkidul dan Kulonprogo

\begin{tabular}{|c|c|c|c|c|c|c|c|}
\hline & & \multicolumn{6}{|c|}{$\begin{array}{l}\text { Levene's Test } \\
\text { for Equality } \\
\text { of Variances }\end{array}$} \\
\hline & & $\mathrm{F}$ & Sig. & $d f$ & $\begin{array}{l}\text { Sig. } \\
\text { (2-tailed) }\end{array}$ & $\begin{array}{l}\text { Mean } \\
\text { Difference }\end{array}$ & $\begin{array}{l}\text { Std. Error } \\
\text { Difference }\end{array}$ \\
\hline \multirow{2}{*}{$\begin{array}{l}\text { Rata-rata } \\
\text { sekolah }\end{array}$} & $\begin{array}{l}\text { Equal } \\
\text { variances } \\
\text { assumed }\end{array}$ & 2,145 & 144 & $-4,085646$ &, 000 & -15681 & 03839 \\
\hline & $\begin{array}{l}\text { Equal } \\
\text { variances } \\
\text { not } \\
\text { assumed }\end{array}$ & & & \multicolumn{2}{|c|}{$-4,006 \quad 483,480,000$} &,- 15681 & ,03914 \\
\hline
\end{tabular}

Sumber: Hasil Penelitian (Data diolah)
Berdasarkan output SPSS diketahui bahwa nilai Sig. sebesar $0,144>\alpha(0,05)$ sehingga dapat disimpulkan bahwa tidak terdapat perbedaan antara rata-rata sikap toleransi siswa Kabupaten Gunungkidul dan rata-rata sikap toleransi siswa Kabupaten Kulonprogo. Dengan demikian indeks sikap toleransi siswa SMA/K di wilayah Gunungkidul dan Kulonprogo tidak memiliki perbedaan yang signifikan.

Selanjutnya perlu juga diketahui dinamika sikap toleransi siswa yang berkembang berdasarkan jenis sekolah, yaitu SMA dan SMK. Dilihat dari perbedaan agama, SMA dan SMK merupakan sekolah umum yang mewadahi siswa yang cenderung heterogen, tidak hanya satu agama. Namun demikian, perlu diukur indeks toleransi siswa di tiga jenis sekolah tersebut

Tabel 8 Indeks Toleransi Siswa Dilihat dari Jenis Sekolah

\begin{tabular}{|c|c|c|c|c|c|}
\hline & jenis sekolah & N & Mean & Std. Deviation & Std. Error Mean \\
\hline \multirow{2}{*}{$\begin{array}{l}\text { Rata } \\
\text { toleransi }\end{array}$} & SMA & 289 & 3,6664 & ,48747 &, 02867 \\
\hline & SMK & 359 & 3,5940 & ,47124 &, 02487 \\
\hline
\end{tabular}

Sumber: Hasil Penelitian (Data diolah)

Tabel di atas menunjukkan rata-rata atau indeks sikap toleransi siswa di SMA dan SMK. Indeks sikap toleransi siswa SMA sebesar 3,67 dan SMK sebesar 3,59. Indeks toleransi siswa pada kedua jenis sekolah tersebut tergolong "tinggi". Berbeda dengan indeks pendidikan multikultural di SMK yang lebih tinggi dibanding SMA, indeks toleransi siswa SMK lebih rendah dibanding SMA, meski dengan selisih atau gap yang relatif kecil.

Untuk menguji signifikansi perbedaan indeks sikap toleransi siswa di SMA dan SMK dilakukan uji beda melalui prosedur independent $t$ test. Dengan menggunakan 
hipotesis yang sama dengan perhitunganperhitungan sebelumnya, diperoleh hasil uji beda sebagai berikut.

Tabel 9 Hasil Uji Beda Indeks Toleransi Siswa Berdasarkan Jenis Sekolah

\begin{tabular}{|c|c|c|c|c|c|c|c|c|}
\hline & & \multicolumn{3}{|c|}{$\begin{array}{l}\text { Levene's Test } \\
\text { for Equality of } \\
\text { Variances }\end{array}$} & \multicolumn{4}{|c|}{ t-test for Equality of Means } \\
\hline & & $\mathrm{F}$ & Sig. & $\mathrm{t}$ & $d f$ & $\begin{array}{l}\text { Sig. } \\
\text { (2-tailed) }\end{array}$ & $\begin{array}{l}\text { Mean } \\
\text { Difference }\end{array}$ & $\begin{array}{l}\text { Std. Error } \\
\text { Difference }\end{array}$ \\
\hline \multirow{2}{*}{$\begin{array}{l}\text { Rata- } \\
\text { rata } \\
\text { sekolah }\end{array}$} & $\begin{array}{l}\text { Equal } \\
\text { variances } \\
\text { assumed }\end{array}$ & ,636 &, 425 & 1,913 & 646 &, 056 & ,07237 &, 03782 \\
\hline & $\begin{array}{l}\text { Equal } \\
\text { variances } \\
\text { not } \\
\text { assumed }\end{array}$ & & & 1,906 & 607,657 & 057 & 07237 &, 03796 \\
\hline
\end{tabular}

Sumber: Hasil Penelitian (Data diolah)

Dengan menggunakan taraf signifikan $\alpha=0,05$ kriteria penolakan $\mathrm{H}_{0}$ jika nilai sig. output $<\alpha(0,05)$. Berdasarkan hasil output SPSS terlihat nilai sig. sebesar $0,425>\alpha$ $(0,05)$, sehingga dapat disimpulkan bahwa indeks sikap toleransi siswa berdasarkan jenis sekolah tidak berbeda secara signifikan.

\section{Kajian Kritis terhadap Pendidikan Multikultural di Sekolah}

Pendidikan multikultural meski tidak secara eksplisit tercantum dalam konstitusi, namun adanya kewajiban penyelenggaraan pendidikan yang setara dan tidak diskriminasi merupakan wujud nyata dari pendidikan multikultural itu sendiri. Dalam Undang-undang Sisdiknas secara tegas mengamanatkan bahwa salah satu prinsip penyelenggaraan pendidikan adalah bahwa pendidikan diselenggarakan secara demokratis dan berkeadilan serta tidak diskriminatif dengan menjunjung tinggi hak asasi manusia, nilai keagamaan, nilai kultural, dan kemajemukan bangsa. Amanat ini berlaku untuk seluruh satuan pendidikan pada setiap jenis, jalur, dan jenjang yang ada.

Pelaksanaan pendidikan multikultural di Gunungkidul dan Kulonprogo sudah baik, yang ditunjukkan oleh indeks pendidikan multikultural yang mencapai 4,06 untuk Gunungkidul dan 4,16 untuk wilayah Kulonprogo. Indeks yang dicapai oleh kedua wilayah tersebut sudah masuk pada kategori "tinggi", akan tetapi belum menjamin terlaksananya pendidikan multikultural secara maksimal di seluruh sekolah.

Pendidikan multikultural di SMA/K di Gunungkidul dan Kulonprogo tidak memiliki perbedaan secara signifikan. Hal ini disebabkan oleh letak geografis kedua wilayah tersebut yang jauh dari perkotaan dan masih didominasi oleh penduduk lokal. Hal ini berimplikasi pada tidak mencoloknya perbedaan latar belakang siswa dari aspek suku, budaya, bahasa, dan agama. Dengan demikian kondisi sosial di lingkungan sekolah cenderung homogen. Meski demikian, keberadaan siswa yang memiliki latar belakang berbeda dengan mayoritas siswa memiliki hak yang sama besar dengan siswa mayoritas.

Kebijakan sekolah dan kurikulum yang merupakan dua di antara tiga variabel penting yang sangat berpengaruh terhadap pelaksanaan pendidikan multikultural perlu menjadi perhatian bersama antara pemerintah dan pihak sekolah, khususnya dalam penyelenggaraan pendidikan agama yang sejalan dengan regulasi yang ada. Di antara sekian banyak sekolah yang ada di Gunungkidul dan Kulonprogo, masih ada beberapa sekolah yang masih melakukan pelanggaran konstitusi dengan tidak menyelenggarakan pendidikan agama di 
luar agama yayasan dan mewajibkan siswa mengikuti pendidikan agama yang tidak sesuai dengan agama yang dianut siswa. Padahal landasan yuridis penyelenggaraan pendidikan agama sudah jelas dan tegas, di antaranya terdapat dalam Pancasila sila pertama, Pembukaan UUD 1945, UU PNPS No. 1 Tahun 1965, UUD 1945 Pasal 29 Pasal 1, UU No. 20 Tahun 2003, Peraturan Pemerintah RI No. 55 Tahun 2007, dan Peraturan Menteri Agama RI No. 16 Tahun 2010. ${ }^{28}$

Dari paparan di atas jelas bahwa penyelenggaraan pendidikan agama di sekolah sudah diatur dan dijamin oleh konstitusi. Sekolah yang dimaksud di sini menurut PMA No. 16 Tahun 2010 adalah sekolah adalah satuan pendidikan formal pada jenjang pendidikan dasar dan menengah yang mencakup TK, SD, SDLB, SMP, SMPLB, SMA, SMALB, dan SMK. Dengan demikian sangat jelas bahwa sekolah wajib menyelenggarakan pendidikan agama bagi siswa sesuai dengan agama yang dianut dan diajarkan oleh guru yang seagama dengan siswa. Sedangkan teknis pelaksanaannya bersifat kondusif berdasarkan jumlah siswa (minoritas) dan kemampuan sekolah.

Sekolah yang tidak menyelenggarakan pendidikan agama selain agama yang dianut yayasan dipengaruhi oleh kebijakan yayasan yang menaunginya, yang notabene merupakan yayasan keagamaan tertentu. Hal ini lazim ditemui di sekolah-sekolah umum yang bercirikan agama tertentu, tidak hanya di wilayah Yogyakarta, akan tetapi juga di wilayah lain di Indonesia. Hal

\footnotetext{
${ }^{28}$ Umi Muzayanah. 2016. Layanan Pendidikan Agama Bagi Siswa Minoritas pada SMA/K di Gunungkidul. Laporan Penelitian belum Dipublikasi. Balai Penelitian dan Pengembangan Agama Semarang, h. 30-31.
}

ini sesuai dengan tulisan Davit Setyawan (2014) dalam kutipan berikut:

\begin{abstract}
"Selama ini masih berlaku sekolah dengan basis keagamaan hanya memberikan pelajaran agama sesuai dengan ciri khas keagamaan sekolah tersebut. Dalam konteks otonomi sekolah, setiap sekolah umum keagamaan berhak hanya menawarkan pelajaran agama sesuai dengan ciri khasnya. Misalnya sekolah Katolik berhak hanya menawarkan pelajaran agama Katolik. Sekolah Kristen hanya menawarkan pelajaran agama Kristen, sekolah Islam hanya menawarkan pelajaran agama Islam. Akan tetapi sekolah tidak berhak mewajibkan siswa-siswanya dari agama lain mengikuti pelajaran agama sesuai dengan cirri khas keagamaan sekolah yang bersangkutan". ${ }^{29}$
\end{abstract}

Tindakan pelanggaran terhadap konstitusi ini dilakukan salah satunya dengan mewajibkan siswa bergama lain untuk mengikuti pelajaran agama yang tidak sesuai dengan agama yang dianutnya. Hal ini perlu adanya kesadaran terhadap kewajiban sekolah dan yayasan untuk memenuhi hak seluruh siswa atas pendidikan agama yang sesuai dengan agama yang dianut.

\section{Ekspresi Keberagamaan Siswa dalam Konteks Toleransi Beragama}

Andil pendidikan multikultural dalam pembentukan sikap toleransi beragama siswa cukup penting untuk diperhitungkan. Hal ini dikarenakan lebih dari enam jam seorang siswa berinteraksi di lingkungan sekolah dan memperoleh tempaan pendidikan di bawah rambu-rambu budaya

${ }^{29}$ Davit Setyawan. 2014. "Implementasi Pendidikan Agama di Sekolah dan Solusinya”. Diakses tanggal 9 Juni 2017 dari www.kpai.go.id. 
sekolah yang diberlakukan. Interaksi sosial yang terjadi di lingkungan sekolah, di mana siswa berangkat dari latar belakang yang berbeda suku dan agama memungkinkan siswa untuk memahami dan menghargai perbedaan yang ada. Sebaliknya, perbedaan yang ada di antara siswa justru tidak menutup kemungkinan melahirkan sikap intoleransi siswa, baik dalam berinteraksi di sekolah maupun di lingkungan masyarakat.

Indeks toleransi siswa pada SMA/K di Gunungkidul mencapai 3,57 dan Kulonprogo mencapai 3,72, yang keduanya berada pada level "tinggi" pada skala 5. Indeks toleransi siswa tertinggi ada pada jenis sekolah SMA sebesar 3,67 disusul oleh SMK dengan indeks toleransi sebesar 3,59. Meski demikian, indeks toleransi siswa di SMA dan SMK tidak memiliki perbedaan secara signifikan.

Sikap toleransi siswa dalam konteks keberagamaan baik di SMA maupun di SMK berada pada level "tinggi". Namun demikian, bukan berarti potensi intoleransi tidak berpeluang untuk tumbuh di kalangan siswa. Apalagi jika bersandar pada hasil riset yang dilakukan oleh The Wahid Institute yang menempatkan Yogyakarta sebagai provinsi kedua dengan jumlah kasus pelanggaran kebebasan beragama tertinggi di tahun 2014 sebanyak 21 kasus, ${ }^{30}$ maka potensi intoleransi di Yogyakarta tidak bisa diabaikan. Berikut deskripsi sebaran wilayah dilihat dari kasus pelanggaran kebebasan beragama dan intoleransi di Indonesia versi The Wahid Institute.

${ }^{30}$ The Wahid Institue. 2014. Laporan Tahunan Kebebasan Beragama/Berkeyakinan dan Intoleransi 2014. Jakarta: The Wahid Institute, h. 26.
Gambar 1 Sebaran wilayah dilihat dari kasus intoleransi di Indonesia

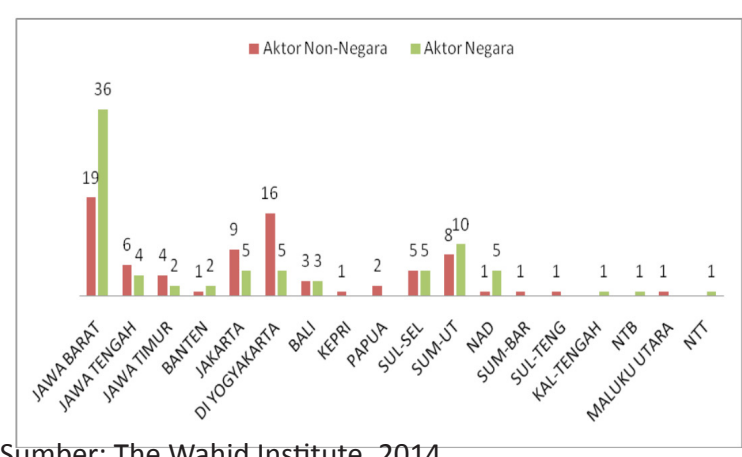

Sumber: The Wahid Institute, 2014.

Angka di atas merupakan kasus pelanggaran kebebasan beragama yang menodai predikat Yogyakarta sebagai city of tolerance. Meskipun 21 kasus intoleransi tersebut bukan kasus pelanggaran yang melibatkan pelajar, namun tidak menutup kemungkinan tindakan intoleransi menyebar ke kalangan pelajar. Hal ini dapat dilihat dari respon siswa SMA/K terhadap aksi kekerasan yang mengatasnamakan agama. Survey dilakukan terhadap 648 siswa dari 15 SMA/K di Gunungkidul dan 10 SMA/K di Kulonprogo. Respon yang diberikan oleh siswa terkait aksi kekerasan yang mengatasnakan agama dapat ditunjukkan pada gambar berikut.

Gambar 2 Respon siswa SMA/K terhadap aksi kekerasan atas nama agama

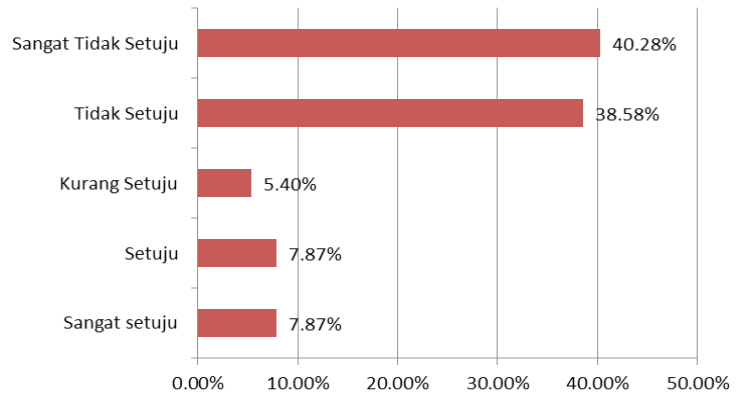

Gambar di atas menunjukkan bahwa siswa SMA/K yang menyatakan "setuju" 
dan "sangat setuju" terhadap aksi kekerasan atas nama agama masing-masing mencapai 7,87\%. Angka tersebut masih cukup kecil jika dibandingkan dengan hasil survey yang dilakukan oleh Lembaga Kajian Islam dan Perdamaian (LaKIP) yang menunjukkan bahwa hampir 50\% dari pelajar setuju tindakan kekerasan demi agama. Survey tersebut dilakukan terhadap siswa SMP dan SMA di beberapa sekolah di Jabodetabek pada kurun waktu Oktober 2010 hingga Januari $2011 .^{31}$

Realitas siswa SMA/K yang "setuju" dan "sangat setuju" terhadap kekerasan atas nama agama yang masing-masing mencapai 7,87\% perlu menjadi perhatian kita bersama, khususnya para penyelenggara pendidikan. Salah satu yang harus dilakukan adalah memberikan pemahaman kepada siswa tentang pentingnya sikap toleransi dan menghargai perbedaan yang ada, termasuk perbedaan agama dan pemahaman agama. Pemahaman dapat diberikan melalui pengembangan budaya sekolah yang multikultur dan pelayanan pendidikan yang setara bagi seluruh siswa. Selain itu, pendidikan agama memiliki peran yang sentral terhadap penyadaran siswa untuk menghargai agama dan keyakinan yang berbeda.

Selanjutnya perlu juga dilihat potensi siswa yang memberikan respon positif terhadap aksi kekerasan atas nama agama jika dilihat dari jenis sekolah, yaitu SMA dan SMK. Hal ini dilakukan mengingat SMA dan SMK sebagai sekolah umum diasumsikan merupakan lembaga pendidikan yang

${ }^{31}$ Ahmad Fuad Fanani,. 2013. "Fenomena Radikalisme di Kalangan Kaum Muda”. MAARIF, 8 (1): 4-13. menyemaikan nilai-nilai toleransi siswa di tengah perbedaan yang ada. Adapun respon siswa terhadap aksi kekerasan atas nama agama jika dilihat dari jenis sekolah dapat digambarkan sebagai berikut.

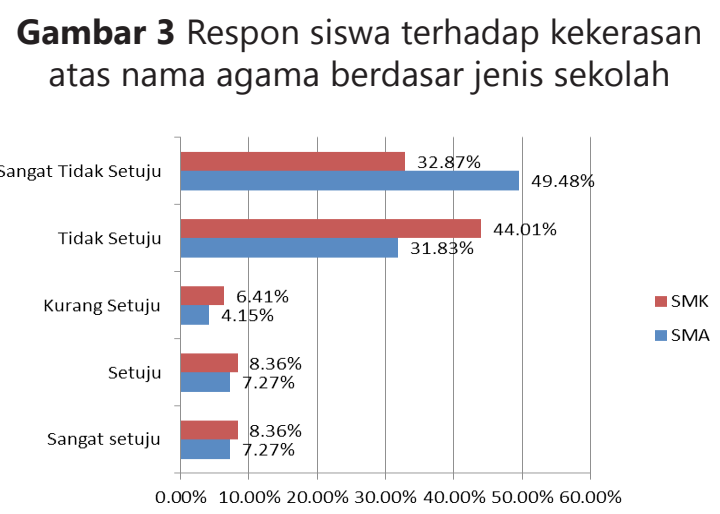

Gambar di atas menunjukkan bahwa persentase siswa SMK yang memberikan respon "setuju" dan "sangat setuju" terhadap aksi kekerasan atas nama agama masing-masing mencapai 8,36\%. Sementara siswa SMA yang menyatakan "setuju" dan "sangat setuju" terhadap kekerasan atas nama agama masing-masing mencapai 7,27\%. Dengan demikian dapat dilihat bahwa jumlah siswa SMK yang setuju terhadap aksi kekerasan atas nama agama lebih tinggi dibanding SMA. Hal ini selaras dengan indeks toleransi siswa SMK yang lebih rendah dibanding siswa SMA (lihat Tabel 8).

Adanya sekelompok siswa yang mendukung positif dengan menyatakan "setuju" dan "sangat setuju" terhadap aksi kekerasan atas nama agama telah membuka mata kita bahwa intoleransi di kalangan siswa SMA/K dapat mengarah pada tindakan kekerasan dan/atau radikalisme atas nama agama. Hal ini dikuatkan oleh hasil survey LaKIP pada tahun 2011, di mana siswa SMP/ SMA yang mengenal organsiasi radikal sebanyak 25,7\% dan siswa yang setuju 
terhadap organisasi radikal sebanyak 12,1\%. Survey tersebut dilakukan pada 100 sekolah di Jabodetabek. ${ }^{32}$

Fenomena tersebut mafhum mengingat siswa SMA/K berada pada usia yang secara psikologis rentan dan belum stabil sehingga mudah menerima provokasi dan pengaruh dari luar. ${ }^{33}$ Hal ini senada dengan pendapat James W. Fowler yang mengatakan bahwa siswa SMA berada pada tahap sintetik konvensional, yaitu tahapan di mana siswa akan patuh terhadap pendapat dan kepercayaan orang lain. Pada tahap ini pula, siswa dapat dengan mudah menerima doktrin dari luar, termasuk doktrin yang bertentangan dengan nilai-nilai agama yang dianutnya. ${ }^{34}$

\section{PENUTUP}

Dari hasil penelitian yang telah dipaparkan pada bab sebelumnya dapat ditarik kesimpulan bahwa pendidikan multikultural yang dilakukan di sekolah jenjang menengah, baik di Gunungkidul maupun Kulonprogo belum bersifat menyeluruh. Meski indeks pendidikan multikultural yang dicapai di Gunungkidul dan Kulonprogo tergolong tinggi, namun pada tataran layanan pendidikan agama belum seluruh sekolah tunduk pada konstitusi yang ada. Hal ini ditunjukkan dengan adanya beberapa sekolah yang tidak memberikan pendidikan agama sesuai

${ }^{32}$ Zuly Qodir. 2013. "Perspektif Sosiologis tentang Radikalisasi Agama Kaum Muda”. MAARIF, 8 (1): 4566.

${ }^{33}$ Ibid.

${ }^{34}$ Syaiful Rizal. 2017. “Tantangan Lembaga Pendidikan dalam Menanggulangi Faham Radikalisme Agama". Edudikara, 2 (1): 72-80. dengan agama siswa, bahkan mewajibkan siswa untuk mengikuti pendidikan agama di luar agama yang dipeluknya.

Di sisi lain, hasil penelitian menunjukkan indeks sikap toleransi siswa di SMA/K, baik di Gunungkidul maupun di Kulonprogo berada pada kategori tinggi. Namun demikian, potensi intoleransi di kalangan siswa bisa tumbuh dan berkembang menjadi ekspresi beragama yang cenderung ekstrim. Hal ini ditunjukkan dengan respon beberapa siswa yang mendukung adanya tindak kekerasan atas nama agama.

Dari hasil penelitian tersebut direkomendasikan kepada pemerintah, khususnya Kementerian Agama dan Kementerian Pendidikan dan Kebudayaan untuk bersinergi dalam upaya melaksanakan pendidikan yang multikultur dengan menerapkan prinsip demokratis dan tidak diskriminasi. Pemerintah memberikan instruksi tegas kepada seluruh yayasan pendidikan untuk memberikan layanan pendidikan agama sesuai dengan agama yang dianut siswa dan diajarkan oleh guru yang seagama dengan siswa. Selanjutnya, menyikapi adanya potensi intoleransi di kalangan siswa, pihak sekolah perlu mengembangkan budaya sekolah yang menghargai perbedaan suku dan agama, dan memberikan pemahaman agama yang penuh kasih sayang.

\section{UCAPAN TERIMA KASIH}

Tulisan ini bersumber dari hasil penelitian yang melibatkan beberapa pihak dalam proses pengumpulan data. Oleh karena itu, ucapan terima kasih penulis sampaikan kepada kepala sekolah beserta jajarannya, guru dan siswa dari beberapa 
SMA/K di Gunungkidul dan Kulonprogo yang telah memberikan support data penelitian. Secara khusus ucapan terima kasih penulis sampaikan kepada Kepala Balai Litbang Agama Semarang yang telah memberikan kesempatan kepada penulis untuk menuntaskan penelitian yang membuahkan tulisan ini.

\section{DAFTAR PUSTAKA}

Adhyatma, Komang (2016): “Street Artist Yogyakarta Bereaksi Mengenai Jargon City of Tolerance". Diakses tanggal 14 Oktober 2016 dari http:// kanaltigapuluh.info/street-artistyogyakarta-bereaksi-mengenai-jargoncity-of-tolerance/.

Al Arifin, Akhmad Hidayatullah (2012): “Implementasi Pendidikan Multikultural dalam Praksis Pendidikan di Indonesia". Jurnal Pembangunan Pendidikan: Fondasi dan Aplikasi, 1 (1): 7282.

Asshiddiqie, Jimly (2014): Toleransi dan Intoleransi Beragama di Indonesia Pasca Reformasi. Makalah disampaikan pada Dialog Kebangsaan tentang "Toleransi Beragama", Ormas Gerakan Masyarakat Penerus Bung Karno, di Hotel Borobudur Jakarta, 13 Februari, 2014.

Baidhawy, Zakiyuddin (2005): Pendidikan Agama Berwawasan Multikultural.Jakarta: Erlangga.

Badan Pusat Statistik. (2015): Daerah Istimewa Yogyakarta Dalam Angka 2015.

Fanani, Ahmad Fuad (2013): "Fenomena Radikalisme di Kalangan Kaum Muda". MAARIF, 8 (1): 4-13.

Fidiyani, Rini (2013): “Kerukunan Umat Beragama di Indonesia: Belajar
Keharmonisan dan Toleransi Umat Beragama di Desa Cikakak Kec. Wangon Kabupaten Banyumas". Jurnal Dinamika Hukum, 13 (3): 468-482.

"FKUB Antisipasi Tindakan Intoleransi Umat Beragama di Kulonprogo". 2015. Diakses tanggal 14 Oktober 2016 dari http:// jogja.tribunnews.com/2015/11/25/ fkub-antisipasi-tindakan-intoleransiumat-beragama-di-kulonprogo.

Ibrahim, Rustam (2013): "Pendidikan Multikultural: Pengertian, Prinsip, dan Relevansinya dengan Tujuan Pendidikan Islam". ADDIN, 7 (1): 129154.

Kusuma, Wijaya (2014): "Slogan "Yogyakarta City of Tolerance" Dipertanyakan". Diakses tanggal 14 Oktober 2016 dari $\quad$ http://regional.kompas. $\mathrm{com} / \mathrm{read} / 2014 / 01 / 31 / 0621376 /$ Slogan.Yogyakarta.City.of.Toleran. Dipertanyakan.

Muzayanah, Umi (2016): Layanan Pendidikan Agama Bagi Siswa Minoritas pada SMA/K di Gunungkidul. Laporan Penelitian belum Dipublikasi. Balai Penelitian dan Pengembangan Agama Semarang.

Prabowo, Danang (2011): "Yogyakarta Dikukuhkan sebagai Kota Toleran". Diakses tanggal 14 Oktober 2016 dari http://news.okezone.com/ $\mathrm{read} / 2011 / 03 / 03 / 340 / 431098 /$ yogyakarta-dikukuhkan-sebagai-kotatoleran.

Putra, Lutfi Mairizal (2017): “Catatan Komnas HAM, Kasus Intoleransi Meningkat Setiap Tahun". Diakses tanggal 22 Juni 2017 dari http://nasional.kompas. $\mathrm{com} / \mathrm{read} / 2017 / 01 / 05 / 18280081 /$ catatan.komnas.ham.kasus.intoleransi. meningkat.setiap.tahun. 
Qodir, Zuly (2013): "Perspektif Sosiologis tentang Radikalisasi Agama Kaum Muda". MAARIF, 8 (1): 45-66.

Rizal, Syaiful (2017): “Tantangan Lembaga Pendidikan dalam Menanggulangi Faham Radikalisme Agama". Edudikara, 2 (1): 72-80.

Setyawan, Davit (2014): Implementasi Pendidikan Agama di Sekolah dan Solusinya. Diakses tanggal 9 Juni 2017 dari http:// www.kpai.go.id/artikel/implementasipendidikan-agama-di-sekolah-dansolusinya/.

Sudrajat, Ajat (Tt): Agama dan Masalah Kekerasan. Diakses tanggal 16 Desember 2016 dari staff.uny.ac.id/system/files/... Ag./Agama\%20dan\%20Masalah\%20 Kekerasan.pdf.

Syaifullah, Muh. (2016): “Yogyakarta Dinilai sebagai Kota Intoleran". Diakses tanggal 14 Oktober 2016 dari https://m.tempo. co/read/news/2016/03/23/058756278/ yogyakarta-dinilai-sebagai-kotaintoleran.

Takwin, Bagus dkk (2016): Studi tentang Toleransid dan Radikalisme di Indonesia Pembelajaran dari 4 Daerah Tasikmalaya, Jogjakarta, Bojonegoro, dan Kupang. International NGO Forum on Indonesian Development.
The Wahid Institue (2014): Laporan Tahunan Kebebasan Beragama/Berkeyakinan dan Intoleransi 2014. Jakarta: The Wahid Institute.

Wibowo, A.M. (2016): Indeks Pendidikan Multikultural di D.I. Yogyakarta. Laporan Penelitian belum Dipublikasi. Balai Penelitian dan Pengembangan Agama Semarang.

Yaqin, M. Ainul (2007): Pendidikan Multikultural Cross-Cultural Understanding untuk Demokrasi dan Keadilan. Yogyakarta: Pilar Media.

Yasir, Muhammad (2014): "Makna Toleransi dalam Al-Quran". Ushuluddin, XXII (2): 170-180.

Yustiani (2015): “Epilog Pendidikan Agama Berwawasan Multikultural". Dalam Pendidikan Multikultural di Pulau Dewata. Ed. Mulyani Mudis Taruna. Yogyakarta: Arti Bumi Intara.

Zamroni (2011): Pendidikan Demokrasi pada Masyarakat Multikultural. Yogyakarta: Gavin Kalam Utama. 